\title{
Wysokość składki ubezpieczenia OC oraz determinanty jej zróżnicowania
}

\author{
MONIKA KOWALSKA \\ Uniwersytet Mikołaja Kopernika w Toruniu, Wydział Nauk Ekonomicznych i Zarządzania \\ e-mail: kontakt@umk.pl
}

SŁoWA KLUCZOWE ubezpieczenia komunikacyjne, ubezpieczenie OC, bonus-malus, składka ubezpieczeniowa, determinanty

StRESZCZENIE W artykule przedstawiono charakterystykę ubezpieczeń, a także opis podstawowego ubezpieczenia komunikacyjnego OC.

Cel - identyfikacja i ocena czynników determinujących wysokość składki na ubezpieczenie OC na przykładzie wybranych firm ubezpieczeniowych działających w Polsce. Dodatkowo, poruszono wątek systemu bonus-malus jako podstawowego czynnika wpływającego na wysokość składki ubezpieczeniowej. Podkreślono kryteria, które należy spełnić, aby zapłacić jak najmniejszą składkę oraz jakie czynniki podwyższają ryzyko wystąpienia zdarzenia drogowego, skutkując wzrostem wysokości składek pobieranych przez ubezpieczycieli.

Metodyka badania - analiza została przeprowadzona na podstawie kalkulacji składek ubezpieczenia odpowiedzialności cywilnej w jednej z toruńskich multiagencji ubezpieczeniowych.

Wynik - na podstawie przeprowadzonych badań wskazano, że rynek ubezpieczeń jest coraz bardziej konkurencyjnym i dynamicznie rozwijającym się rynkiem.

Oryginalność - artykuł ma charakter teoretyczno-empiryczny. Jest uniwersalny, ponieważ dotyczy wszystkich kierowców, nie tylko pasjonatów tematu. Problematyka niniejszej pracy jest bardzo istotna, poprzez swój globalny charakter. Artykuł przygotowano według stanu prawnego na dzień 1 maja 2016 roku.

\section{An altitude of liability insurance premium and the determinants of it's differentiation}

KEYWORDS motor insurance, liability insurance, system bonus-malus, insurance premium, determinants

The article presents the characteristics of insurance and the description of the basic motor liability insurance.

Purpose - the article aims to identify and evaluate factors determining the amount of insurance of civil liability on the basis of selected insurance companies in Poland. You can also read about system bonus-malus, which is a fundamental factor affecting the altitude of insurance premium. In the article highlighted the requirements that must be meet to pay as little premium and what factors increase the risk of a traffic incident, resulting in an increase in premiums charged by insurers.

Methodology - the analyze was based on calculation insurance of civil liability in one of the insurance multiagencies in Toruń.

Findings - the research shows that insurance market is increasingly competitive and rapidly growing market. 
Value - the article has a theoretical and empirical character. Also, it should be added that it is unique, because it applies to all drivers, not just passionate about the subject. The issue of article is very important through its global nature. This article was prepared by the legal status as od 1 May 2016.

\section{Wprowadzenie}

Rynek ubezpieczeń komunikacyjnych kryje w sobie duży potencjał rozwojowy, jest konkurencyjny i pełen zależności. Świadczy o tym wzrastająca liczba zarejestrowanych samochodów w Polsce, wpływająca na przyrost zawartych umów ubezpieczenia komunikacyjnego. Wzrastająca liczba samochodów na ulicach znacznie przyczynia się do powstawania szkód w postaci wypadków lub kolizji. To z kolei oddziałuje na zmianę postrzegania kierowcy przez zakład ubezpieczeń na bardziej niebezpieczny, co w efekcie powoduje wzrost wysokości składki ubezpieczeniowej. Należy zwrócić uwagę na to, jak ubezpieczyciele ,wybierają” swoich odbiorców spośród wszystkich kierowców, dostosowując przykładowo wysoką składkę ubezpieczeniową dla młodych kierowców, a niższą dla starszych, w ich mniemaniu, bardziej doświadczonych kierowców. Celem artykułu jest rozpoznanie i ocena determinantów składki ubezpieczenia, aby jeszcze dogłębniej poznać specyfikę rynku ubezpieczeń.

\section{Ubezpieczenia komunikacyjne - zagadnienia podstawowe}

Współcześnie pojęcie ubezpieczenia jest wszystkim dobrze znane dzięki rosnącej popularności ochrony przed wszelkimi wypadkami losowymi oraz szerokiemu wachlarzowi dostępnych ofert ubezpieczeniowych na rynku. Wśród ubezpieczeń komunikacyjnych z pewnością najbardziej znane i zasługujące na największą uwagę jest ubezpieczenie OC posiadacza pojazdu mechanicznego. Ubezpieczenia OC zalicza się do ubezpieczeń majątkowych z grupy ubezpieczeń gospodarczych. Stanowią one najważniejszy segment polskiego rynku ubezpieczeń i od wielu lat obejmują ponad 60\% rynku ubezpieczeń majątkowych (Madej, Madej, Michniak, Kurcz, 2015, s. 79). Wynika to głównie z ich powszechnego wykorzystywania - tak z chęci asekuracji, jaki i obowiązku zawierania tego typu ubezpieczeń. Pojęcie odpowiedzialności można definiować jako świadome przewidywanie przyszłych zdarzeń będących skutkiem działań i decyzji człowieka. Innymi słowy, jest to ponoszenie konsekwencji za własne zachowania, a czasem nawet zachowania innych (Szewieczek, 2013, s. 338). Obowiązek zawarcia umowy ubezpieczenia odpowiedzialności cywilnej spoczywa na każdym posiadaczu pojazdu mechanicznego.

Ubezpieczenie to sposób zabezpieczania się przed skutkami zdarzeń losowych, polegający na przeniesieniu ryzyka z poszkodowanego na instytucję zapewniającą ochronę ubezpieczeniową. Ma to na celu przywrócenie stabilności finansowej i wyrównanie uszczerbku majątkowego przez wypłatę należytego odszkodowania (Sułkowska, 2001, s. 18). Wanda Sułkowska trafnie ujęła tę definicję mówiąc, że ubezpieczenie to mechanizm umożliwiający zamianę niepewnej lecz wielkiej straty, czyli zdarzenia losowego, niewielką lecz pewną stratą - składką ubezpieczeniową (2001, s. 32). Podpisując umowę, strony ubezpieczenia zobowiązują się do należytego spełniania swoich obowiązków. W artykule 805 §1 k.c. (Dz.U. 2016, poz. 380 z późn. zm.) 
widnieje zapis, że ,przez umowę ubezpieczenia ubezpieczyciel zobowiązuje się (...) spełnić określone świadczenie w razie zajścia przewidzianego w umowie wypadku, a ubezpieczający zobowiązuje się zapłacić składkę". Ubezpieczyciel ponosi ryzyko wystąpienia zdarzenia opisanego w umowie i w związku z tym, jego zadaniem jest pokrycie określonych strat i wypłata należnego ubezpieczonemu świadczenia. Rolą ubezpieczyciela jest także określenie wysokości składki, tak aby zapewnić całemu zakładowi ubezpieczeń bezpieczeństwo finansowe, by przez lata, dzięki zgromadzonej znacznej ilości składek ubezpieczeniowych, był zdolny do wypłaty większych, ale rzadszych świadczeń swoim ubezpieczonym. Ubezpieczony w zamian za ochronę płaci składkę ubezpieczeniową. Świadczenie obu stron ma charakter pieniężny, przy czym ubezpieczony płaci składkę okresowo, a ubezpieczyciel - jednorazowo w razie zajścia nieszczęśliwego wypadku (Wąsiewicz, 1991, s. 17). Składka spotykana w zakładach ubezpieczeń złożona jest z dwóch części - składki netto, zwanej czystą oraz ze składki brutto, nazywanej całkowitą. Składka netto przeznaczona jest tylko i wyłącznie na wypłatę świadczenia ubezpieczeniowego, natomiast zwiększając ją o różnego rodzaju dodatki - tworzy się składkę brutto. Na te dodatkowe koszty składają się koszty administracyjne, koszty pozyskiwania ubezpieczeń, akwizycji oraz na zysk danego zakładu ubezpieczeń (Spigarska, 2008, s. 80).

Wyróżnia się kilka zasad ustalania składek ubezpieczeniowych, są to trzy „złote” reguły ubezpieczeniowe (Zapart, 2014, s. 350):

1. Zasada równowagi składek i świadczeń - inaczej jest to zasada równowagi finansowej; oznacza, że pomiędzy wpłacanymi składkami a wypłacanymi odszkodowaniami musi być zachowana równowaga.

2. Zasada proporcjonalności składek i świadczeń - oznacza, że pomiędzy wpłacaną składką a wypłacanym odszkodowaniem musi być zachowana odpowiednia, proporcjonalna relacja. Wysokość składki uzależniona jest od wysokości sumy ubezpieczeniowej, więc im wyższa suma ubezpieczenia, tym wyższa wpłacana składka i wyższe wypłacane świadczenie.

3. Zasada równowartości składek i świadczeń (zasada składki sprawiedliwej) - oznacza, że wpłacane składki są uzależnione od indywidualnego rozmiaru ryzyka. Stawka dla każdego ubezpieczonego ma inną wielkość i jest liczona pojedynczo, co niesie za sobą wysokie koszty techniczne.

\section{Czynniki kształtujące składkę ubezpieczeniową OC}

Kryteria ustalania składki ubezpieczeniowej różnią się w zależności od zakładu ubezpieczeń, jednak najczęściej są nimi (Porównywarka Finansowa Comperia, 2012):

- wiek kierowcy - osoba młoda jest uznawana za mniej doświadczoną, a więc ryzyko wystąpienia wypadku jest większe,

- okres posiadania prawa jazdy - dłuższy może świadczyć o większej praktyce oraz mniejszej częstotliwości szkód,

- miejsce zamieszkania kierowcy - według statystyk w niektórych powiatach mieszkańcy są bardziej narażeni na wystąpienie wypadku, występuje tam większa szkodowość, 
- dane techniczne samochodu, czyli marka, model, rok produkcji, pojemność silnika - im większa moc, tym większa prędkość, a co za tym idzie - większe ryzyko pojawienia się szkody,

- kolor samochodu - jasne kolory uznawane są za bezpieczniejsze, ponieważ są bardziej widoczne po zmroku, dzięki temu prawdopodobieństwo zaistnienia zdarzenia losowego $\mathrm{z}$ takim pojazdem jest mniejsze,

- liczba rat - im jest ich więcej, tym większa składka; najkorzystniejsza jest jednorazowa zapłata, jednak pociąga to za sobą konieczność zgromadzenia dużej ilości pieniędzy jednorazowo,

- sposób zapłaty składki - zakłady ubezpieczeń, stając się bardziej mobilne, mogą oferować zniżki w przypadku kupna ubezpieczenia przez internet,

- cel używania pojazdu - jeżeli jest on wykorzystywany jako taksówka, pojazd zastępczy lub pojazd nauki jazdy, wtedy rośnie ryzyko wystąpienia zdarzenia ze względu na większą częstotliwość jazdy; skutkuje to zwiększeniem wysokości składki ubezpieczeniowej,

- przebieg - wyższy przebieg świadczy o większym zużyciu pojazdu, a także o pogarszającym się stanie technicznym, co sprawia, ze pojazd staje się bardziej niebezpieczny na drodze,

- stan cywilny oraz potomstwo - osoby będące w stałym związku lub mające rodzinę są traktowani jako bardziej rozważni i ostrożni kierowcy, dlatego mogą otrzymać z tego tytułu pewne zniżki.

Mimo tak wielu czynników, największe znaczenie ma system bonus-malus oparty na indywidualnej historii szkodowości danego kierowcy (Cieślik, 2013, s. 14). Taryfa składek zakładu ubezpieczeń to uporządkowany zbiór stóp składek, uwzględniający klasy ryzyka z tzw. bonusami, czyli rabatami oraz malusami, czyli karami doliczanymi do składki. System bonus-malus odpowiednio zmniejsza lub zwiększa składkę ubezpieczeniową proporcjonalnie do zmiany ryzyka w stosunku do wartości przeciętnej (Zapart, 2014, s. 349). Uzależniony jest od zachowania właściciela pojazdu - czy jeździ on w szkodowy czy też w bezszkodowy sposób (Daszewski, 2010). Klasyfikacja prowadzona jest w sposób skrupulatny i dokładny, z indywidualnym podejściem do klienta.

Każdy zakład ubezpieczeń stosuje własny system BM (bonus-malus), ze względu na to, że nie jest on regulowany żadną ustawą. Różnice miedzy ofertami poszczególnych towarzystw ubezpieczeń dla jednakowego produktu mogą być znaczne, co wynika z różnych konstrukcji taryf. Liczba czynników, rodzaj i procentowe wartości zniżek i zwyżek są bardzo odmienne i często ulegają zmianom (Cieślik, 2013, s. 19), jednak konstrukcja ustalania wysokości składki jest ta sama. Najpierw określa się składkę podstawową, włączając klienta do określonej grupy taryfowej, a następnie przystępuje się do korekty tej składki (Cieślik, 2013, s. 15). Korekta wynika z przyporządkowania ubezpieczonego do danej klasy i polega na doliczaniu do składki bonusów lub malusów. W przypadku wystąpienia szkody, przy przedłużaniu lub zawieraniu nowej umowy ubezpieczenia, zakład ubezpieczeń ma prawo doliczyć zwyżkę w kolejnym roku umowy, przez co kierowca wnosi się o dwa poziomy w górę tabeli BM. Za bezszkodową jazdę ubezpieczony otrzymuje natomiast zniżkę składki i spada o poziom w dół. Gdy kierowca nie ma historii szkodowości to zaczyna od poziomu 0 (Zakład Ubezpieczeń Proama Generali TU SA, 2014). 
Tabela 1. Przykładowa klasyfikacja kierowcy do danej klasy ryzyka

\begin{tabular}{|c|c|c|}
\hline Klasa taryfy & Procent podstawowej składki & Liczba bezszkodowych lat \\
\hline-3 & 160 & III składka podwyższona \\
\hline-2 & 140 & II składka podwyższona \\
\hline-1 & 120 & I składka podwyższona \\
\hline 0 & 100 & składka podstawowa \\
\hline 1 & 90 & po roku \\
\hline 2 & 80 & po 2 latach \\
\hline 3 & 70 & po 3 latach \\
\hline
\end{tabular}

Źródło: opracowanie własne.

W tabeli 1 zaprezentowano tradycyjny system BM. Ubezpieczony może ją znaleźć w OWU danego ubezpieczenia. Obecnie na rynku największą zniżkę bonus-malus dla bezszkodowych kierowców, wynoszącą 70\% dla ubezpieczenia OC, oferuje towarzystwo Proama Generali TU SA (Zakład Ubezpieczeń Proama Generali TU SA, 2014). Największą zwyżkę w wysokości 260\% składki ubezpieczeniowej można uzyskać natomiast w TUiR Allianz Polska SA (TUiR Allianz Polska SA, 2009).

Powyższe przykłady determinant zróżnicowania składek mają charakter poglądowy i nie odnoszą się do działalności wszystkich zakładów ubezpieczeń. Ważne jest zatem zapoznanie się z Ogólnymi Warunkami Ubezpieczenia wybranego zakładu ubezpieczeń.

\section{Wyniki badań kalkulacji składek ubezpieczeniowych}

Kalkulację składek ubezpieczenia OC przeprowadzono w jednym z toruńskich towarzystw ubezpieczonych. Spośród wielu czynników determinujących wysokość składki OC w badaniach uwzględniono następujące (cztery) zmienne: miejsce zamieszkania, wiek kierowcy, rodzaj pojazdu oraz zakład ubezpieczeń. Reszta czynników oddziałujących na składkę dla każdej kalkulacji była taka sama. Zaprezentowane w tabeli 2 kwoty stanowią tylko podstawę składki. Zakład ubezpieczeń każdego kierowcę traktuje indywidualnie. Oprócz zniżek pochodzących z systemu BM, ubezpieczyciel może zaoferować zniżki marketingowe w ramach obowiązujących promocji. W związku z powyższym, kalkulacje mają charakter czysto poglądowy.

Dobór próby badawczej jest subiektywny. Autor zastrzega sobie swobodę w wyborze analizowanych determinant. Badane miejscowości zlokalizowane są w województwach kujawsko-pomorskim oraz podkarpackim z identyczną powierzchnią (w granicach 17 tys. $\mathrm{km}^{2}$ ), a także identyczną liczbę ludności (ok. $2 \mathrm{mln}$ ). Liczba ludności Torunia wynosi ponad 200 tys. przy powierzchni $116 \mathrm{~km}^{2}$, a w Ustrzykach Dolnych niecałe 10 tys. przy $17 \mathrm{~km}^{2}$. W województwie podkarpackim odnotowuje się jednak większą liczbę wypadków niż w województwie kujawsko-pomorskim (Komenda Główna Policji, 2007). Do badania wzięto pod uwagę kierowców w trzech kategoriach wiekowych: 18-latka z niewielkim doświadczeniem, prowadzącego bez świadomości ryzyka jakie niesie za sobą jazda samochodem; 40-latka będącego dobrym i pewnym kierowcą, odpowiednio pokornego, z wiedzą i doświadczeniem zdobytym w trakcie długich lat jazdy oraz 65-latka będącego wyszkolonym kierowcą, lecz miewającego problemy zdrowotne oraz coraz mniej możliwości. W poniższym przykładzie porównano Škodę Fabię, która jest 
samochodem średniej klasy o przeciętnej pojemności silnika z Toyotą Land Cruiser - luksusowym pojazdem o dużej pojemności silnika, który osiąga duże prędkości i może być uznawany jako potencjalne zagrożenie dla innych uczestników ruchu drogowego. Dodatkowo, nazwy towarzystw ubezpieczeń zamieniono na zakład A, B i C, aby nie faworyzować lub nie działać na niekorzyść żadnego towarzystwa.

W tabeli 2 zaprezentowano wyniki badań własnych w zakresie kalkulacji wysokości składki ubezpieczenia OC na podstawie oferty wybranych ubezpieczycieli. Kolorem ciemnoszarym zaznaczono najwyższe składki w danym zakładzie, natomiast kolorem jasnoszarym - najniższe. Pierwszy czynnik, który zostanie przeanalizowany to wiek kierowcy, następnie miejscowość, rodzaj posiadanego pojazdu oraz zakład, z którym kierowca zawiera umowę ubezpieczenia.

Tabela 2. Kalkulacja składki ubezpieczenia OC

\begin{tabular}{|l|c|c|c|}
\hline \multicolumn{1}{|c|}{ Miejscowość } & 18-latek & 40-latek & 65-latek \\
\hline \multicolumn{4}{|c|}{ Škoda Fabia (zł) } \\
\hline Toruń - zakład A & 2631 & 1126 & 1126 \\
\hline Toruń - zakład B & 5414 & 1116 & 1144 \\
\hline Toruń - zakład C & 6445 & 1667 & 1600 \\
\hline Ustrzyki - zakład A & 1710 & 742 & 639 \\
\hline Ustrzyki - zakład B & 2814 & 625 & 1398 \\
\hline Ustrzyki - zakład C & 5623 & 1456 & 5300 \\
\hline \multicolumn{5}{|c|}{ Toyota Land Cruiser (zł) } \\
\hline Toruń - zakład A & 12650 & 5300 & 1730 \\
\hline Toruń - zakład B & 8744 & 1777 & 2506 \\
\hline Toruń - zakład C & 9680 & 2406 & 3203 \\
\hline Ustrzyki - zakład A & 7616 & 3203 & 2103 \\
\hline Ustrzyki - zakład B & 4516 & 2190 & \\
\hline Ustrzyki - zakład C & 8459 & 938 & \\
\hline
\end{tabular}

Źródło: opracowanie własne na podstawie danych liczbowych z Towarzystwa Ubezpieczeń.

Zakład A dla 40- i 65-letniego kierowcy ustala wysokość składki na tym samym poziomie. Zakład B dla 65-letniego kierowcy mieszkającego w Ustrzykach Dolnych stosuje zwyżki wiekowe i zwiększa składkę, biorąc pod uwagę jego utracone umiejętności jazdy wzrastające wraz z wiekiem. Zakład C natomiast, dla tego samego kierowcy, pomniejsza składkę ubezpieczeniową, zakładając, że doświadczenie nabywa się z wiekiem. Dla 18-letniego kierowcy składki są znacznie wyższe - w zakładzie A posiadając samochód Škoda Fabia zapłaci najtańsze ubezpieczenie, a Toyotę Land Cruiser - najdroższe ze względu na dużą moc pojazdu. Znaczy to, że zakład ewidentnie ustala wysokość składki tak, aby jak najmniej młodych kierowców zdecydowało się na współpracę. W takiej sytuacji zakład nie musi ponosić odpowiedzialności za mniej doświadczonych kierowców, w wypadku których ryzyko wystąpienia zdarzenia jest znacznie większe niż u osób dojrzałych. Tym samym - nie jest zobowiązany do gromadzenia dużej ilości środków pieniężnych na wypłatę świadczeń na rzecz ubezpieczonych.

Najniższa składka dla mieszkańca Ustrzyk Dolnych posiadającego Škodę Fabia wyniosła 625 zł, a Toyotę Land Crusier - 938 zł, przy czym najwyższa składka dla tego samego mieszkańca 
wyniosła odpowiednio 5623 zł oraz 8459 zł. W Toruniu najniższa składka ubezpieczenia wynosi 1116zł dla pojazdu Škoda Fabia, a 1730 zł dla pojazdu Toyota Land Cruiser. Najwyższe składki wynoszą natomiast odpowiednio 6445 zł oraz 12650 zł. Niezależnie od wieku i posiadanego pojazdu każdy kierowca musi zapłacić wyższą składkę w Toruniu w porównaniu z Ustrzykami Dolnymi. Mimo że w podkarpackiej miejscowości odnotowano większą liczbę wypadków w latach 2007-2014, to gęstość zaludnienia będąca 20 razy mniejsza niż w Toruniu ma większe znaczenie przy ustalaniu składki. Podsumowując powyższe dane, można zauważyć, że kierowca pojazdu mechanicznego zarejestrowanego w większym mieście zapłaci wyższe ubezpieczenie OC.

Mając na uwadze rodzaj pojazdu, można wysnuć jeden wniosek, że dla każdego kierowcy najbardziej korzystne byłoby poruszanie się Škodą Fabią, ponieważ wysokość składki ubezpieczeniowej dla tego pojazdu będzie niższe niż dla Toyoty Land Cruiser. Niezależnie od wieku kierowca posiadający Toyotę Land Cruiser będzie opłacał najwyższe składki ze względu na dużą pojemność silnika samochodu. Większa pojemność silnika powoduje możliwość osiągnięcia dużej prędkości, co przekłada się na większe ryzyko wystąpienia zdarzenia losowego oraz większe koszty odszkodowania po zaistniałej szkodzie. Poruszając się Škodą Fabią najdroższe ubezpieczenie zapłaci 18-latek z Torunia, bo aż 6445 zł, a najtańsze - 40-latek z Ustrzyk Dolnych, w wysokości 625 zł. Przy potencjalnej zmianie samochodu z analizowanej Škody Fabii na ujęty w kalkulacji model Toyoty obserwuje się wyraźny wzrost składki ubezpieczeniowej. Aż 12650 zł będzie musiał zapłacić 18-letni mieszkaniec Torunia, przy czym najniższa składka ubezpieczenia 65-letniego kierowcy z Ustrzyk Dolnych będzie wynosiła zaledwie 962 zł. Najwyższa składka jest trzynastokrotnością najtańszej, dlatego warto przeprowadzić kalkulację u kilku ubezpieczycieli, żeby nie przepłacać.

Z danych zaprezentowanych w tabeli 2 wynika, że w każdym przypadku 18-letni kierowca jest zobowiązany do zapłaty najwyższego ubezpieczenia. Dla młodego kierowcy z Torunia posiadającego Škodę Fabię najdroższe ubezpieczenie, z którego z pewnością nie skorzystałby, zostało zaproponowane przez zakład C i było to prawie 250\% najtańszej składki. Różnica między najdroższym a najtańszym ubezpieczeniem wynosi aż 3814 zł w Toruniu oraz 3913 zł w Ustrzykach Dolnych. Dla 40-letniego kierowcy Škody Fabia najtańsze ubezpieczenie oferuje zakład B zarówno w Toruniu, jak i w Ustrzykach Dolnych, gdzie jest ono niższe o 491 zł. Różnica w składce pomiędzy zakładem A oraz B wynosi zaledwie 10 zł w Toruniu, a 117 zł w Ustrzykach Dolnych. 40-latek zapłaci najwyższą składkę w zakładzie C, niezależnie od miejsca zamieszkania. Dla 65-letniego kierowcy Škody Fabia najdroższą ofertę ubezpieczenia proponuje zakład C, a najtańszą - zkład A w Toruniu i zakład B w Ustrzykach Dolnych. Przy zmianie samochodu na Toyotę Land Cruiser okazuje się, że zakład A wyliczył najwyższą ofertę ubezpieczenia a zakład B - najniższą w każdym przypadku.

Biorąc pod uwagę powyższe cztery determinanty, można stwierdzić, że kalkulacja składki ubezpieczenia OC w największym stopniu zależy od wieku kierowcy. Zakłady ubezpieczeń ustalając składki kierują się tym, z którymi klientami chcieliby rozpocząć współpracę. Wyznaczając składkę na wysokim poziomie, zakład wyraźnie zaznacza, że niechętnie będzie ponosił ryzyko wystąpienia zdarzenia losowego u danego kierowcy. Zwłaszcza w przypadku 18-letniego kierowcy zakłada się, że jest on niedoświadczony, co wiąże się z częstym występowaniem wypadków lub kolizji, a tym samym koniecznością wypłaty odszkodowania. Ponadto, niektóre zakłady 
zawyżają składki dla starszych kierowców zakładając, że z wiekiem pogarsza się ich szybkość reakcji, wzrok i słuch. Dodatkowo istnieje ryzyko pojawienia się dolegliwości zdrowotnych podczas prowadzenia pojazdu, co również może skutkować zdarzeniem losowym.

\section{Podsumowanie}

W artykule wyraźnie podkreślono kryteria, które należy spełnić, aby zapłacić jak najmniejszą składkę oraz jakie czynniki podwyższają ryzyko wystąpienia zdarzenia drogowego, skutkując wzrostem wysokości składek pobieranych przez ubezpieczycieli.

Najistotniejszy wniosek z przeprowadzonej kalkulacji jest taki, że 18-latek jeżdżący samochodem o dużej pojemności silnika, osiągającym duże prędkości, mieszkający w mieście o dużej liczbie ludności jest uznawany przez badanych ubezpieczycieli jako potencjalne zagrożenie, w związku z tym jest on zmuszony do płacenia najwyższych składek. Takie czynniki podwyższają ryzyko wystąpienia zdarzenia drogowego, więc ubezpieczyciele muszą pobierać wysokie składki, aby móc później wypłacić należne odszkodowanie po zaistniałej szkodzie, co zazwyczaj kilku lub kilkunastokrotnie przewyższa wysokość składki. Najmniejszą składkę na ubezpieczenie OC zapłaci kierowca samochodu o średniej pojemności silnika, pochodzący z niewielkiej miejscowości i mający około 40 lat, który porusza się po drogach z rozwagą i doświadczeniem. Doliczając do tego nagromadzone zniżki za poprzednie bezszkodowe lata jazdy oraz indywidualnie dopasowane zniżki marketingowe oferowane przez ubezpieczyciela, wysokość składki staje się bardzo sensowna i w małym stopniu obciąża budżet kierowcy. Warto dbać o bezszkodowość i bezpiecznie poruszać się po drogach z dwóch względów - aby niepotrzebnie nie zwiększać wydatków na wysokie ubezpieczenie OC oraz, co ważniejsze, nie powodować wypadków czy kolizji. Skutki tych ostatnich bardzo często są dotkliwe a wartość powstałych szkód majątkowych - wysoka, dlatego należy dążyć do zmniejszenia ich liczby.

Warto również podkreślić, że ubezpieczycielom zależy na zadowoleniu klientów, dlatego pragnęliby zrekompensować wszelkie powstałe szkody. Należy jednak wziąć pod uwagę, że ich budżet jest ograniczony, a jeżeli szkodowość będzie rosła - zwyżce podlegać będą również składki ubezpieczeniowe.

\section{Literatura}

Cieślik, B. (2013). System bonus-malus jako narzędzie konkurencji na rynku ubezpieczeń komunikacyjnych. Warszawa: Wydawnictwo Poltex.

Daszewski, A. (2010). Kto i jak ustala taryfy składek za ubezpieczenie OC posiadaczy pojazdów mechanicznych? Czy sq $w$ tym zakresie regulacje prawne? Pobrano z: http://rf.gov.pl/pytania-i-odpowiedzi/ubezpieczeniakomunikacyjne-odpowiedzialnosci-cywilnej-oc-zasady-ogolne/Kto_i_jak_ustala_taryfy_skladek_za_ubezpieczenie_OC_posiadaczy_pojazdow_mechanicznyh__Czy_sa_w_tym_zakresie_regulacje_p__20271 (11.04.2016).

Kodeks Cywilny z 23.04.1964 r. (Dz.U. 2016 poz. 380 z późn. zm.).

Komenda Główna Policji (2007). Pobrano z: http://statystyka.policja.pl/st/ruch-drogowy/76562,Wypadki-drogowe-raporty-roczne.html, (28.04.2016)

Madej, B., Madej, R., Michniak, J., Kurcz, J. (2015). Ubezpieczenia dla transportu. Warszawa: Akademia Transportu i Przedsiębiorczości. 
Porównywarka Finansowa Comperia (2012). Pobrano z: http://ub.comperia.pl/co-wplywa-na-wysokosc-skladki-ubezpieczenia-oc.html (26.04.2016).

Spigarska, E. (2007). Zasady kalkulacji składki ubezpieczeniowej w zakładach ubezpieczeń. Prace i Materiały Wydziat Zarządzania UG. Rachunkowość wybrane aspekty, 4.

Sułkowska, W. (2001). Ubezpieczenia. Zagadnienia podstawowe. Kraków: Oficyna wydawnicza TEXT.

Szewieczek, D. (2013). Ubezpieczenia odpowiedzialności cywilnej. W: M. Iwanicz-Drozdowska (red.), Ubezpieczenia. Warszawa: PWE.

TUiR Allianz Polska SA (2009). Pobrano z: https:/www.allianzdirect.pl/dokumenty-do-pobrania/tabela_bonus_ malus.pdf (11.04.2016).

Wąsiewicz, A. (1991). Nowe ubezpieczenia samochodowe oraz przystugujące z ich tytułu odszkodowania. Gdańsk: Kancelaria Prawnicza „Lex” S.A.

Zakład Ubezpieczeń Proama Generali TU SA (2014). Pobrano z: http://insus.pl/wp-content/uploads/2014/03/zasady-Bonus-Malus.pdf (11.04.2016).

Zakład Ubezpieczeń Proama Generali TU SA, (2014). Pobrano z: https:/www.proama.pl/ubezpieczenie_samochodu/ warto_wiedziec/70_procent_znizki_na_oc_ac/ (11.04.2016).

Zapart, T. (2014). Kalkulacja składki ubezpieczeniowej w ubezpieczeniach komunikacyjnych dla podmiotów gospodarczych. W: W. Ronka-Chmielowiec (red.), Ubezpieczenia wobec wyzwań XXI wieku. Wrocław: Wydawnictwo Uniwersytetu Ekonomicznego we Wrocławiu.

\section{Cytowanie}

Kowalska, M. (2016). Wysokość składki ubezpieczenia OC oraz determinanty jej zróżnicowania. Współczesne Finanse. Teoria i Praktyka, 1 (1), 25-33. DOI: 10.18276/wf.2016.1-03. 